\title{
KONSEP PEMBELAJARAN PAI DALAM AL-QUR'AN SURAH LUQMAN AYAT 12-19
}

\author{
MOHAMMAD IQBAL \\ Pascasarjana UIN Alauddin Makassar \\ Kampus II: Jalan Sultan Alauddin Nomor 36 Samata-Gowa
}

\begin{abstract}
Abstrak :
Penelitian ini bertujuan untuk; 1)mendeskripsikan Bagaimana metode pembelajaran PAI dalam al-Qur'an, 2) Mengemukakan Bagaimana konsep pembelajaran PAI dalam al-Qur'an surah luqman ayat 12-19, 3) menganalisis implikasi dampak pembelajaran PAI dalam al-Qur'an surah luqman ayat 12-19. Penelitian ini tergolong library research, data yang dikumpulkan dengan mengutip, menyadur, dan menganalisis dengan menggunakan analisis pengumpulan data terhadap literatur yang representatif dan mempunyai relevansi dengan masalah yang dibahas, kemudian mengulas dan menyimpulkannya. Hasil penelitian dalam tesis ini mengungkap sosok seseorang hamba yang sholeh yang bernama Luqman dia berasal dari Habsy (Ethiopia). Orang-orang menggelar hamparan untuknya, membuka lebarlebar pintu untuknya dan amat senang dengan perkataannya. Dan beliau juga di juluki seorang pendidik yang baik. Dia senang tiasa mendidik anaknya untuk bertauhid dan tidak berbuat kesyirikan, dan memberikan penjelasan untuk meninggalkannya. Kemudian beliau juga memerintahkan kepada anaknya untuk senangtiasa berbuat baik kepada kedua orang tua dan menerangkan tentang penderitaan orang tua selama ia di dalam kandungan. Akan tetapi apabila kedua orang tuamu memerintahkan untuk berbuat kesyirikan maka jangan sekali-kali melakukannya. Abu darda berkata menceritakan Luqman al-Hakim: dia tidak pernah diberikan sesuatu seperti keluarga, harta, kehormatan dan sesuatu hal akan tetapi dia adalah seseorang yang tangguh, pendiam, pemikir dan berpandangan dalam. Maka dari itu dia diberikan pemahaman tentang islam, padahal dia bukan seorang nabi dan tidak diberikan wahyu.

Kata Kunci: PAI, konsep pembelajaran pai
\end{abstract}

\section{PENDAHULUAN}

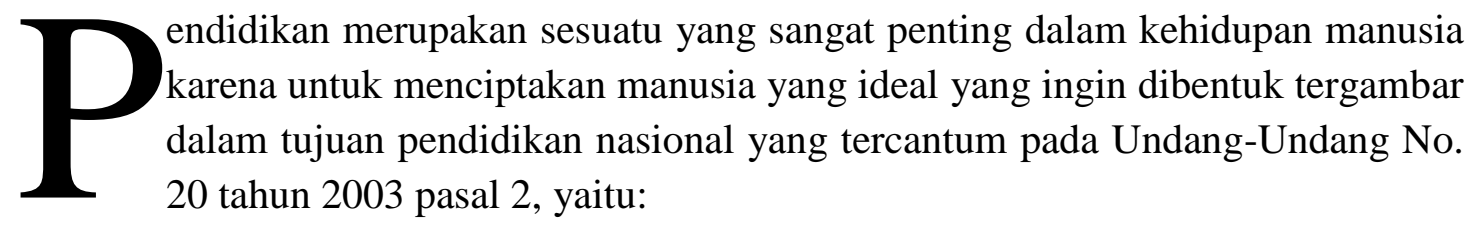

Bekembangnya potensi peserta didik agar menjadi manusia yang beriman dan bertakwa kepada Tuhan Yang Maha Esa, berakhlak mulia, sehat, berilmu, cakap, 
kretif, mandiri, dan menjadi warga negara yang demokratis serta bertanggung jawab. ${ }^{1}$ Tujuan pendidikan nasional juga tercantum dalam Undang-Undang No. 2 tahun 1989 pasal 4, yaitu: Pendidikan Nasional bertujuan mencerdaskan kehidupan bangsa dan mengembangkan manusia Indonesia seutuhnya, yaitu manusia yang beriman dan bertaqwa terhadap Tuhan Yang Maha Esa dan berbudi pekerti luhur, memiliki pengetahuan dan keterampilan, kesehatan jasmani dan rohani, kepribadian yang mantap dan mandiri serta rasa tanggung jawab kemasyarakatan dan kebangsaan. ${ }^{2}$

Sistem Pendidikan Nasional ditetapkan ketentuan sebagaimana di sebutkan pada pasal 1 dan 2 antara lain:

1. Pendidkan adalah usaha sadar dan terencana untuk mewujudkan suasana belajar dan proses pembelajaran agar peserta didik secara aktif mengembangkan potensi dirinya untuk memilki kekuatan spritual keagamaan, pengendalian diri, kepribadian, kecerdasan akhlak mulia, serta keterampilan yang diperlukan dirinya, masyarakat, bangsa dan negara.

2. Pendidikan nasional adalah pendidikan yang berdasarkan Pancasila dan UndangUndang Dasar Negara Republik Indonesia Tahun 1945 yang berakar pada nilainilai agama, kebudayaan nasional Indonesia terhadap tuntunan perubaghan zaman. ${ }^{3}$

Nilai-nilai islam demikian itulah yang seharusnya ditumbuhkembangkan dalam diri manusia melalui proses transpormasi kependidikan. Suatu proses yang bisa mengarahkan seseorang selalu berorientasi kepada kekuasaan Allah Swt dan iradatnya dalam menentukan segala keberhasilannya. Bagi manusia yang berkepribadian islam akan tetap merasa berada dalam lingkaran hubungan vertikal dengan Tuhannya dan hubungan horizontal dengan masyarakat. ${ }^{4}$ Allah swt. Mengingatkan dalam QS Lukman ayat 31 :

Terjemahnya:

Dan sesungguhnya telah Kami berikan hikmat kepada Luqman, yaitu: "Bersyukurlah kepada Allah. dan barangsiapa yang bersyukur (kepada Allah), maka sesungguhnya ia bersyukur untuk dirinya sendiri; dan barangsiapa yang tidak bersyukur, maka sesungguhnya Allah Maha Kaya lagi Maha Terpuji". 5

Sifat syukur merupakan landasan dalam sifat penghambaan manusia terhadap penciptanya. Salah satu dasar tauhid dan penyembahan kepada Allah swt. didasari rasa

\footnotetext{
1. Departemen Pendidikan Nasional RI, Undang-Undang RI Nomor 20 Tahun 2003 tentang Sisitem Pendidikan Nasional (Jakarta: Departemen Pendidikan Nasional Ri, 2003), h.3

${ }^{2}$ Departemen Pendidikan Nasional RI, Undang-Undang RI Nomor 2 Tahun 1989 tentang Sistem Pendidikan Nasional (Jakarta: Sinar Grafika 1995 ), h. 4

${ }^{3}$ Abdul Rachman Shaleh, Pendidikan Agama \& Pembangunan Watak Bangsa, Jakarta : PT Raja Grafindo Persada 2005, h. 15

4. H.M. Arifin, Ilmu Pendidikan Islam (Jakarta: PT Bumi Aksara, 2003), h. 2

${ }^{5}$ Kementerian Agama RI. Al-Qur'an dan Terjemahnya, h. 412.
} 
syukur kepadanya karena dia telah menciptakan kita. Orang yang musrik tidak mau bersyukur kepada Allah swt. karena mereka lupa dan kufur terhadap proses penciftaan dirinya. Oleh sebab itu, kufur nikmat merupakan kufur terhadap Allah swt. Orang yang tidak bersyukur berarti menghina Allah swt, durhaka, dan tidak mengerti siapa Allah swt sebenaranya tidak mungki Allah swt akan menambah nikmat kepada orang yang tidak bersyukur.

\section{METODE PENELITIAN.}

Dalam melakukan penelitian ini penulis menggunakan beberapa pendekatan, yaitu pendekatan ilmu tafsir dan linguistik. Penelitian ini tergolong library research, data yang dikumpulkan dengan mengutip, menyadur, dan menganalisis dengan menggunakan analisis pengumpulan data terhadap literatur yang representatif dan mempunyai relevansi dengan masalah yang dibahas, kemudian mengulas dan menyimpulkannya.

\section{HASIL DAN PEMBAHASAN.}

\section{A. Pendidikan Islam dalam Al-Qur'an}

pendidikan dalam al-Qur'an mempunyai banyak istilah beberapa istilah yang sering digunakan adalah rabba-yurabbi (mendidik), "allama-yuallimu" (member ilmu), addaba-yuaddibu (member teladan dalam akhlak), dan darrasa-yudarrisu (memberikan pengetahuan). Berikut ini disajikan pengertian istilah tersebut yang bersumber dari al-Quran dan hadis. ${ }^{6}$

\section{Rabba-yurabbi}

Istilah rabba-yurabbi terdapat dalam al-Quran QS Al-Isra/17: ayat 24 sebagai berikut:

Terjemahnya:

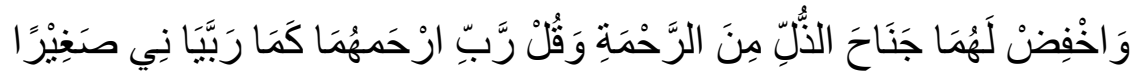

Dan rendahkanlah dirimu terhadap keduanya dengan penuh kasih sayang dan ucapkanlah, "wahai tuhanku! Sayangilah keduanya sebagaiman mereka berdua telah mendidik aku pada waktu kecil. ${ }^{7}$

Kata Rabb juga dinisbahkan kepada nama Allah yang berarti pendidik dan sekaligus pemelihara bagi segala makhluk-Nya. Perhatikan firman Allah QS. AlFatiha/1: ayat 2 berikut:

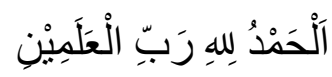

\footnotetext{
${ }^{6}$ Ridwan Abdullah Sani, Muhammad Kadri, Pendidikan Karakter (Jakarta: PT Bumi Aksara, 2016), h. 8

${ }^{7}$ Kementerian Agama RI. Alquran dan Terjemahnya (Jakarta: Pustaka Agung Harapan, 2010), h. 284
} 
Terjemahnya:

Segala puji bagi Allah, Tuhan (Rabb) seluruh alam. ${ }^{8}$

Rabba-yurabbi memiliki masdar yakni tarbiyah. Naquaib al-Attas dalam bukunya mengemukakan bahwa pada dasarnya tarbiyah bemakna memelihara, mengarahkan, member makan, mengembangkan, menyebabkan tumbuh dewasa, menjaga, menjadikan berhasil, dan menjinakkan. Penerapan tarbiyah tidak terbatas pada manusia saja, namun juga pada spesies lainnya seperti tumbuhan dan hewan. Oleh sebab itu, konsep tarbiyah dapat dikaitkan dengan peternakan ayam, penambakan ikan, dan perkebunan. Tujuan tarbiyah biasanya bersifat fisik karena hannya terkait dengan pertumbuhan yang bersifat kebendahan.

Pendidikan yang diberikan oleh pendidik sebagai murabbi pendidik sebagai murobbi haruslah sejalan dengan sifat Allah tersebut. Pendidik yang kapasitasnya sebagai murabbi seharusnya memiliki kebiasaan dan tingkah laku yang baik, serta mampu menyesuaikan diri dengan anak didiknya. Pendidik harus dapat menjadi figur bagi anak didiknya yang memainkan peranan yang baik agar mereka dapat mengambil contoh dan suri teladan, serta menjadi pelindung agar mereka merasa aman.

\section{Allama-Yuallimu}

Seorang pendidik juga dapat disebut mu'allim. Kata mu'allim berasal dari akar kata 'allama-yu'allimu (memberi ilmu) dan ungkapan ini sesuai dengan firman Allah QS. Al-Baqarah/2 : ayat 31 berikut.

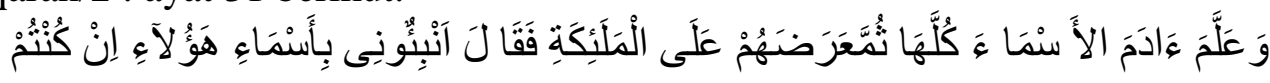

صَادِقِيْنَ

Terjemahnya:

Dan dia ajarkan (memberi ilmu) kepada Adam nama-nama (benda) semuanya, kemudian Dia perlihatkan kepada para malaikat, seraya berfirman "sebutkan kepadaKu nama semua (benda) ini, jika kamu yang benar!. ${ }^{9}$

Ayat tersebut menjelaskan tentang pengajaran kepada Nabi Adam. Setelah beliau diciptakan oleh Allah. Nabi Adam diajarkan oleh Allah nama-nama benda yang dapat dicapai oleh kekuatan manusia, baik dengan pancaindra maupun akal. Jadi, Allah memberikan ilmu kepada Adam agar mengetahuai apa yang sebelumnya tidak diketahuinya. Berdasarkan ayat tersebut, sebutan mu'allim lebih sesuai diberikan kepada seorang pendidik yang menteransfer atau memberikan ilmu pengetahuan kepada peserta didik tentang sesuatu yang tidak mereka ketahui sebelumnya. Seorang

${ }^{8}$ Kementerian Agama RI. Alquran dan Terjemahnya (Jakarta: Pustaka Agung Harapan, 2010), h. 1

${ }^{9}$ Kementerian Agama RI. Alquran dan Terjemahnya (Jakarta: Pustaka Agung Harapan, 2010), h. 6 
$m u$ 'allim mengajari peserta didik mulai dari mereka tidak tahu tentang sesuatu sampai mereka memahaminya. Masdar dari 'allama yu' 'allimu adalah ta 'lim. Ta 'lim bermakna pengajaran dan pendidikan, namun secara umum ta lim hanya terbatas pada pengajaran dan pendidikan secara kognitif. ${ }^{10}$

\section{Addaba-Yuaddibu}

Seorang pendidik juga dapat disebut mu'addib. Mu'addib berasal dari akar kata addaba-yuaddibu yang artinya memberikan teladan dalam akhlak. Isim fa'il dari addaba-yu'addibu adalah mu'addib. Istilah adab merupakan istilah dasar dalam islam dan telah banyak dibahas oleh para ulama terkait maknanya dalam pandangan Islam. Istilah $a d a b$ dapat ditemukan dalam hadis berikut.

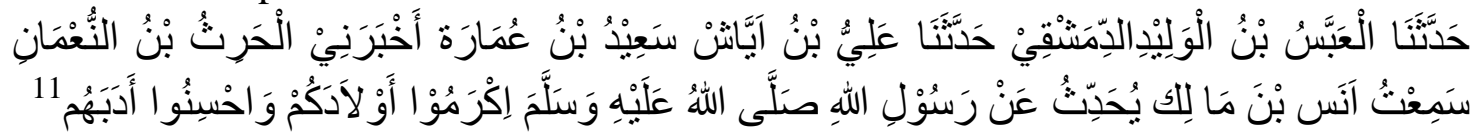

Artinya:

Telah menceritakan kepada kami Al-Abbas bin Al-Walid Ad-Dimasyqi, telah menceritakan kepada kami Ali bin 'Ayyasy, telah menceritakan kepada kami Sa'id bin 'Umarah, telah mengabarkan kepadaku Al-Harits bin An-Nu'man mendengar Anas bin Malik dan ri Rasulullah beliau bersabda, "muliakanlah anak-anak kalian dan perbaikilah tingkah laku mereka.(HR. Ibnu Majah)

Adapun pengertian al-ta' dib di dalam hadis

$$
\text { اََدَبَنِي رَبِّي فَاَحْسنِي تَادِدِبي (حديث قدسي }
$$

\section{Darrasa-Yudarrisu}

Kata pendidik juga dapat diambil dari kata darrasa-yudarrisu. Ism fa'il kata darrasa-yudarrisu adalah mudarris. Mudarris adalah orang yang memiliki kepekaan intelektual dan informasi; memperbaharui pengetahuan dan keahliannya secara berkelanjutan; berusaha mencerdaskan peserta didik; memberantas kebodohan; serta melatih keterampilan sesuai dengan bakat, minat dan kemampuan peserta didik.

pendidikan dan pengajaran yang sesuai denngan al-Qur'an dan sunnah kepada peserta didik. Hal tersebut sesuai dengan sabda Rasulullah berikut.

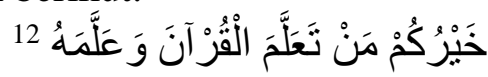

Artinya:

"Sebaik-baik kalian adalah orang yang belajar al-Qur'an dan mengajarkannya".

Prinsip diatas mengajarkan kepada orangtua maupun guru bahwa untuk menjadi seorang pendidik harus memiliki beberapa kriteria berikut. ${ }^{13}$

${ }^{10}$ Ridwan Abdullah Sani, Muhammad Kadri, Pendidikan Karakter (Jakarta: PT Bumi Aksara, 2016), h. 10.

${ }^{11}$ Abu Abdullah Muhammad bin Yazid Al-Qazwini, Terjemah Sunan Ibnu Majah (Jakarta: CV Asy Syifa 2009), h. 1373

${ }^{12}$ Muhammad Ilham Nur, Ketika al-Qur'an Tak Lagi di Agungkan (Jakarta: PT Elex Media Komputindo, 2017), h. 39 
1) Kemampuan Pedagogis

Kemampuan pedagogis adalah kemampuan yang harus dimiliki oleh seorang penidik dalam hal mentransfer ilmu kepada peserta didik. Kemampuan ini mencakup pemahaman terhadap sifat peserta didik dari segala aspek, seperti pisik, moral, spritual, sosial, kultural, emosional, dan intelektual.

2) Kemampuan Pribadi

Kemampuan pribadi terkait dengan kepribadian pendidik yang harus dapat menjadi teladan bagi peserta didiknya atau sifat uswah hasanah dalam konsep islam. Pendidik seharusnya dapat menjadi teladan, baik dari cara berfikir (pengetahuan akademik) maupun akhlak (sikap dan perilaku).

3) Kemampuan sosial

Kemampuan sosial yang perlu dimiliki oleh seorang pendidik mencakup kompetensi dalam bersosialisasi dengan orang lain, terutama dalam berkomunikasi. Pendidik adalah figur yang diharapkan dapat menjadi teladan yang bukan saja kepada peserta didik, melainkan juga pada lingkungan, baik lingkungan sekolah maupun lingkungan rumah.

4) Kemampuan akademik

Kemampuan yang sangat penting bagi seorang pendidik adalah memiliki kemampuan akademik. Kemampuan akademik adalah penguasaan seorang pendidik terhadap materi yang akan diajarkan kepada peserta didik.

\section{B. Nilai-Nilai Pembelajaran PAI dalam QS Luqman Ayat 12-19.}

Luqman al-Hakim adalah seorang yang bijak atau memiliki kata-kata hikmah sebagaiman pembahasan sebelumnya. dan dia juga adalah seorang pendidik terutama terhadap anak-anaknya. Sehingga diabadikan di dalam al-Quran Dan dapat dijadikan suri teladan dalam mendidik anak sehingga anak menjadi manusia yang selalu bertakwa kepad Allah swtdan patuh kepada orang tua. adapun hal-hal yang terkandung dalam metode pendidikan Luqman al-Hakim tersebut. Yakni berupa rumusan tujuan pendidikan yang jelas, menggambarkan sistimatika pendidikan serta penjenjangan yang berkelanjutan untuk menciptakan manusia yang bertauhid dan berakhlah yang mulia. Adapun nilai-nilai pembelajaran PAI yang terkandung dalam QS Luqman ayat 12-19

1. Pendidikan Aqidah/Tauhid

Pendidikan aqidah/tauhid adalah merupakan pendidikan pertama yang harus diberikan kepada anak-anak, agar sejak dini mengenal Allah swt Maha kuasa atas segala sesuatu dan dialah yang menciptakan alam semesta termasuk manusia dan diri anak itu sendiri. Adapun pendidikan tauhid yang terkandung di dalam QS. Luqman adalah larangan menyekutukan Allah dan meyakini adanya tempat kembali.

2016), h. 13

${ }^{13}$ Ridwan Abdullah Sani, Muhammad Kadri, Pendidikan Karakter (Jakarta: PT Bumi Aksara, 
a. Tidak Menyekutukan Allah swt.

Luqman al-Hakim memprioritaskan pendidikan tauhid kepada anaknya tauhid yang menjadi wasial Luqman yang utama, di dalam QS. Luqman ayat 13. Pengajaran dan pendidikan ketauhidan yang dilakukan oleh Luqman kepada anaknya setara dengan nasihat Nabi Ya'kub a.s. kepada anaknya yang dinyatakan dalam QS alBaqarah ayat 133 .

Terjemahnya:

Adakah kamu hadir ketika Ya'qub kedatangan (tanda-tanda) maut, ketika ia berkata kepada anak-anaknya: "Apa yang kamu sembah sepeninggalku?" mereka menjawab: "Kami akan menyembah Tuhanmu dan Tuhan nenek moyangmu, Ibrahim, Ismail dan Ishaq, (yaitu) Tuhan yang Maha Esa dan Kami hanya tunduk patuh kepada-Nya". ${ }^{14}$

Ayat diatas menunjukkan bahwa kekhawatiran utama Nabi Ya'kub jika ia meninggal adalah hilangnya ketauhidan pada diri anak-anaknya, walaupun beliau selalu mengajarkan ketauhidan kepada mereka. Oleh sebab itu, ketauhidan merupakan dasar utama yang harus ditanamkan dalam diri anak. Sebaiknya, tanamkan rasa keimanan yang murni sejak dini karena anak sudah dapat menerima pendidikan keimanan pada usia tersebut dengan baik. ${ }^{15}$ Prinsip yang perlu ditanamkkan kepada anak adalah pada hakikatnya hanya ada satu zat yang wajib disembah. Yakni Allah swt. Sebagai mana di dalam QS al-Baqarah/2:163 berikut.

Terjemahnya:

Dan Tuhanmu adalah Tuhan yang Maha Esa; tidak ada Tuhan melainkan Dia yang Maha Pemurah lagi Maha Penyayang. ${ }^{16}$

Luqma al-Hakim melarang anaknya menyekutukan Allah dengan alsan bahwa perbuatan syirik merupakan sebuah dosa yang amat besar. Risalah utama yang dikemukakan oleh Rasulullah saw. bahwa syirik adalah dosa yang paling besar dan tidak akan diampuni oleh Allah swt, sebagaiman QS an-Nisa/4:116 berikut.

Terjemahnya:

Sesungguhnya Allah tidak mengampuni dosa mempersekutukan (sesuatu) dengan Dia, dan Dia mengampuni dosa yang selain syirik bagi siapa yang dikehendaki-Nya. Barangsiapa yang mempersekutukan (sesuatu) dengan Allah, Maka Sesungguhnya ia telah tersesat sejauh-jauhnya. ${ }^{17}$

Tauhid adalah ajaran yang disampaikan oleh para nabi dan Rasul sejak Nabi Adam as. Hingga Nabi Muhammad saw. pada umumnya, Allah mengutus rasul ketika masyarakat telah menyimpang dari ajaran tauhid. Hukuman Allah swt. Atas perbuatan syirik sangat berat karena syirik menyebabkan bercabangnya kecintaan kepada Allah

\footnotetext{
${ }^{14}$ Kementerian Agama RI, al-Qur'an dan Terjemah, (Bandung: Sygma Publishing, 2010), h. 20

${ }^{15}$ Ridwa Abdullah Sani, Pendidikan Karakter (Jakarta: PT. Bumi Aksara, 2016), h. 167

${ }^{16}$ Kementerian Agama RI, al-Qur'an dan Terjemah, (Bandung: Sygma Publishing, 2010), h. 24

${ }^{17}$ Kementerian Agama RI, al-Qur'an dan Terjemah, (Bandung: Sygma Publishing, 2010), h. 97
} 
swt, berkhianatnya hati, berbagi pengabdian kepada selain Allah swt. Dan merupakan penghinaan kepada Allah swt. Jadi, sangat wajar jika Allah swt. Marah kepada orang yang mengada-adakan tuhan selain Allah swt.

Perhatikan bahwa perilaku animisme terkadang masih dimiliki oleh masyarakat di sekitar kita, misalnya percaya bahwa sebuah jimat, batu cincin, keris, dan benda mati lainnya memiliki kekuatan tersendiri. Ada juga yang berbuat syirik dengan pergi kekuburan atau dukun dengan maksud meminta bantuan untuk memperlancar usaha. Didiklah anak agar menjauhi perbuatan syirik yang jelas dan yang hampir tidak terasa. Syirik yang tidak terasa adalah percaya bahwa ada pertolongan yang bukan dari Allah. Sebagai contoh, sembuh dari penyakit semata-mata karena obat, dapat memiliki keuntungan semata-mata karena usaha, dan sebagainnya. Perlu diingat bahwa orang sakit memang perlu mengonsumsi obat, namun pada hakikatnya kesembuhan merupakan izin dari Allahswt.

Banyak ditemui berbagai kepercayaan yang mengandung unsur syiirik, mulai dari menuhankan selain Allah hingga anggapan terhadap suatu benda yang dipercayai dapat memberikan mudarat dan keberuntungan secara gaib. Syirik akan melemahkan jiwa dan kepribadian karena menggantungkan keberuntungan dang menganggap bahwa nasibnya ditentukan oleh selain Allah swt. Kepribadian orang musrik pecah karena menggantungkan daya kekuatannya pada benda, padahal benda itu akan hancur. Oleh sebab itu, orang musrik takut kepada alam dan tegak karena tahayul. Hal tersebut dikarenakan apa yang menjadi kepercayaan mereka selain Allah swt. Adalah alam belaka. Jiwa mereka terbelenggu karena menjadi budak dari alam dan takut, tunduk, serta mengabdi kepada sesuatu selain Allah. Manusi sebagai makhluk dan khalifah Allah swt. Di muka bumi, hendaknya langsung memohon kepada Allah swt, bukan perantara lewat benda atau bahkan pada benda itu sendiri.

Aqidah yang kuat akan menjauhkan manusia dari syirik atau mempersekutukan Allah swt. Dengan tuhan-tuhan lain. Sebagaimana hadis dari dari al Abbas bin Abdul Muththalib, bahwasanya Rasulullah saw. bersabda

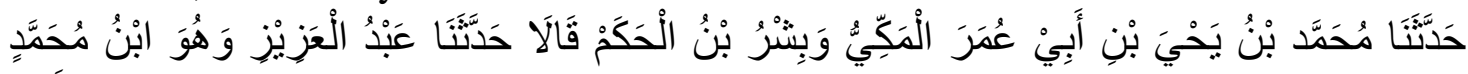

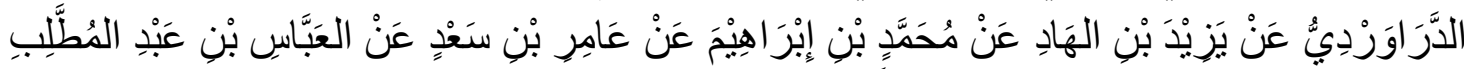

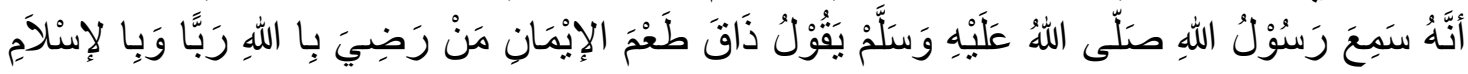

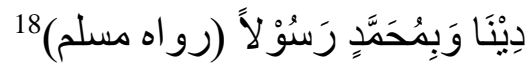

Artinya:

Telah menceritakan kepada kami Muhammad bin Yahya bin Abu Umar al-Makki dan Bisyr bin al-Hakam keduanya berkata, telah menceritakan kepada kami Abdul Aziz yaitu Ibnu Muhammad ad-Darawardi dari Yazid bin al-Had dari Muhammad bin Ibrahim dari Amir bin sa'ad dari al-Abbas bi Abdul Muththalib bahwa dia mendengar

18 Abil Husain, Muslim bin al Hajjaj al Qusyairie an Naisaburie. "Sohih Muslim", (Beirut, Libanon: Darul Fikri 2013), h.41 
Rasulullah saw. Bersabda" orang yang ridho dengan Allah sebagai Rab dan islam sebagai agama serta Muhammad sebagai Rasul, maka dia telah merasakan nikmatnya iman".

Aqidah yang baik akan membawa manusia menjadi baik, sebagai tanda bahwa manusia itu baik adalah paham akan agama islam dengan baik pula. Sebagaimana sabda Rasulullah saw.

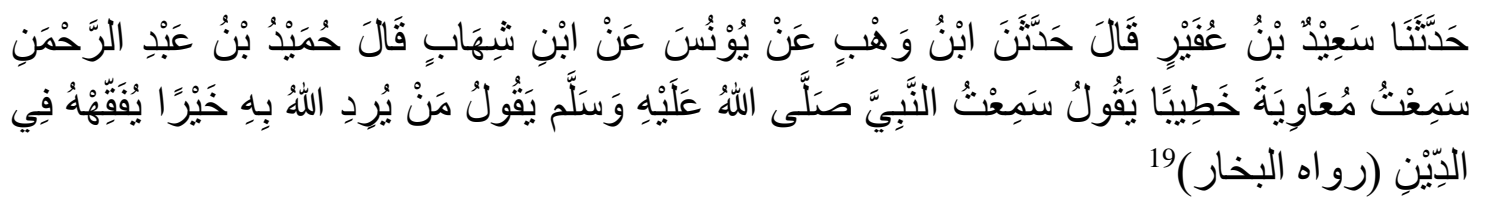

Artinya:

Telah menceritakan kepada kami sa'id bin Ufair telah menceritakan kepada kami Ibnu Wahab dari Yunus dari Ibnu Syihab berkata, Humaid bin Abdurrahman berkata; aku mendengar Mu'awiyah memberi khutbah untuk kami, dia berkata; aku mendengar Nabi saw. Bersabda: "Barang siapa yang di kehendaki oleh Allah menjadi baik, maka Allah akn memberikan pemahaman tentang agama ini

b. Mengajarkan Bahwa Setiap Perbuatan Akan Diberikan Balasan Oleh Allah swt.

Luqman mengajarkan kepada anaknya bahwa setiap perbuatan manusia pasti ada balsannya sebagaiman dinyatakan pada ayat ke 16 QS Luqman. Penegasan tentang balasan atas perbuatan manusia selama hidup di dunia juga dinyatakan di dalam QS alZalzalah ayat 7-9.

Terjemahnya:

Barangsiapa yang mengerjakan kebaikan seberat dzarrahpun, niscaya Dia akan melihat (balasan)nya. Dan Barangsiapa yang mengerjakan kejahatan sebesar dzarrahpun, niscaya Dia akan melihat (balasan)nya pula. ${ }^{20}$

Pada ayat tersebut menjelaskan bahwa setiap perbuatan yang dilakukan manusia di dunia akan diberikan balasan di akhirat sesuai dengan kadar yang dilakukan di dunia. Orang tua perlu mengajarkan anak bahwa sebagai sebagai orang yang beriman hendaklah bertindak dengan berorientasi pada akhirat. Artinya, menimbang dan memikirkan segala sesuatu yang dilakukan di dunia akan diminta pertanggungjawabannya di akhirat. Hal tersebut diharapkan akan membuat mereka selalu berhati-hati dalam bertindak dan berupaya menenmpuh jalan kebaikan.

Orang tua perlu menjelaskan kepada anak bahwa akhirat atau hari akhir yang dimaksud adalah setelah kiamat. Anak perlu diajarkan untuk percaya pada kejadian di hari akhir yang mencakup padang mahsyar, hisab, siratalmustakim, surga, dan neraka, serta semua peristiwa akhirat lainnya. Jika keyakinan kepada Allah swt. Dan hari akhir

\footnotetext{
${ }^{19}$ Abdul Majid Khon, Hadis Tarbawi (Jakarta: Kencana Prenada Media Group, 2012), h. 22

${ }^{20}$ Kementerian Agama RI, al-Qur'an dan Terjemah, (Bandung: Sygma Publishing, 2010), h.
} 
telah diresapi, pendidikan spritiual dan pembentukan karakter lainnya akan lebih mudah untuk dilakukan.

2. Pendidikan Syariah/Ibadah

Pendidikan syariah atau ibadah adalah pendidikan yang berusaha mengenalkan, menanamkan dan menghayatkan anak terhadap nilai-nilai peraturan Allah swt tentang tata cara pengaturan perilaku hidup manusia. dapun muamalah yaitu bentuk peribadatan yang bersifat umum, pelaksanaannya tidak seluruhnya dicontohkan langsung oleh Nabi, namun beliau hanya meletakkan prinsip-prinsip dasar, sedangkan pengembangannya diserahkan kepada kemampuan dan daya jangkau ummat. Seperti ekonomi, bisnis, jual beli, perbankan, perkawinan, pewarisan, pidana, tatata negara dan sebagainya. Adapun nilai-nilai pendidikan syariah/ibadah yang terdapat dalam QS Luqman ayat 12-19 antara lain:

a. Perintah Mendirikan Shalat

Mendirkan shalat bermakna menjalankan shalat tanpa ada yang tertinggal. Shalat adalah ibadah utama setelah mentauhidkan Allah swt dan harus dilatihkan kepada anak semenjak dini. Perintah selanjutnya yang dikemukakakan oleh Luqman kepada anaknya adalah menyeru manusia untuk berbuat kebaikan dan mencegah berbuat kemungkaran sebagaimana yang terdapat pada ayat 17 QS surah Luqman. Perintah untuk shalat ternyata diberikan kepada ummat terdahulu, namun tata cara yang dilakukan mungkin berbeda. Sebagai informasi, jika kita pelajari kitab suci yang diturunkan oleh Allah swt kepada nabi sebelum nabi Muhammad saw. sebenarnya juga terdapat perintah untuk bersujud kepada Allah swt.

Ketekunan dalam mengajak anak dan keluarga dalam mengerjakan shalat perlu dilakukan karena kualitas iman selalu berubah, adakalnya anak malas mengerjakan shalat atau sibuk dengan aktivitasnya, misalnya ketika anak sedang bermain. Tanggung jawab orang tua dalam mendidik anak untuk menjadi manusia yang bertakwa kepada Allah merupakan syarat untuk dapat digolongkan ke dalam ahli surga. Jika anak dan keluarga tidak melaksanakan shalat, Allah akan memberikan ganjaran berupa neraka jahannam, sebagaiman dinyatakan di dalam QS al-Qiyamah ayat 31

Terjemahnya:

Dan ia tidak mau membenarkan (Rasul dan Al Quran) dan tidak mau mengerjakan shalat $^{21}$

Shalat merupakan sarana komunikasi antara manusia dengan Allah swt. Jika shalat dilakukan dengan khusyuk, kemungkinan komunikasi yang dilakukan akan diterima oleh Allah swt. Sehingga kita akan merasa tenang dalam hidup dan Allah swt. Tidak akan meninggalka kita. Jika shalat dilakukan dengan tergesa-gesa dan tidak

\footnotetext{
${ }^{21}$ Kementerian Agama RI, al-Qur'an dan Terjemah, (Bandung: Sygma Publishing, 2010), h.
} 
ikhlas, Allah swt. Pasti akan meninggalkan kita yang bermaksud menghadap kepadaNya. Jika Allah telah meninggalkan kita, tidak ada yang menjamain keselamatan atas diri kita di dunia dan di akhirat. Hal tersebut perlu dijelaskan oleh orang tua kepada anak ketika mengajarkan mereka untuk mendirikan shalat.

Orang tua perlu mengajarkan bahwa shalat adalah tiang agama yang menopang semua amalan yang dilakukan oleh seorang muslim. Tanpa mendirikan shalat maka bangunan agama akan runtuh. Pentingnya kedudukan shalat dinyatakan dalam hadis berikut

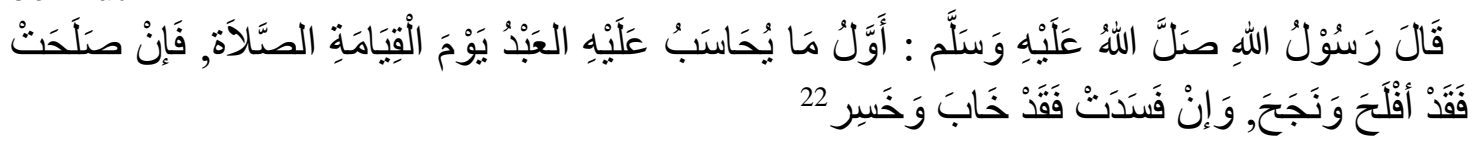

Terjemahannya:

Rasulullah saw. Bersabda: permulaan amal perbuatan seorang hamba yang dihisab (dihitung) di hari kiamat ialah shalatnya, apabila shalatnya baik maka sungguh dia telah beruntung, dan apabila shalatnya rusak maka sungguh dia telah merugi.

Orang tua harus mengajak anak untuk mengerjakan shalat pada waktunya sehingga anak disiplin dan tertib dalam melaksanakan shalat. Penegakan disiplin dalam shalat membutuhkan ketegasan orang tua maupun guru. Oleh sebab itu, pada upaya pengajaran shalat dapat dilakukan dengan memberikan hukuman. Anak juga perlu diajarkan tentang arti bacaan shalat agar dapat memahami setiap langkag dalam yang dilakukan. Jika seseorang dapat menjiwai shalat yang merupakan sarana untuk berkomunikasi dengan Allah swt. Shalat dapat mencegah perbuatan dosa dan munkar. Jika ada seseorang yang shalat, namun perbuatannya sehari-hari tidak benar maka dapat dipastikan bahwa shalat yang dilakukan belum khusyuk.

Banyak orang tua yang merasa kesulitan ketika menyuruh anak melaksanakan shalat. Hal yang perlu diperhatikan untuk mengatasi permasalahan tersebut adalah dengan mengambil pelajaran dari luqman dalam mendidik anak. Strategi yang dilakukan Luqman sebelum menyuruh anaknya shalat, yaitu:

1) Menanamkan tauhid kepada anak;

2) Berbuat baik kepada kedua orang tua;

3) Bersyukur kepada Allah swt;

4) Menanamkan kepada anak bahwa segala sesuatu yang dilakukannya pasti akan diberikan ganjaran oleh Allah swt.

Setelah empat hal tersebut diajarkan kepada anak, barulah menyuruh anak untuk melaksanakan shalat. Anak perlu dididik untuk melaksanakan shalatdengan ikhlas sehingga merasa tidak dipaksa dan selanjutnya anak akan mendirikan shalat secara mandiri tanpa diperintah oleh orang tuanya. Hal tersebut dapat terwujud karena dalam hati anak sudah tertanam ketauhidan kepada Allah swt. Dan hatinya cenderung patuh

22 Abu Malik Kamal Bin Sayyid Salim, Sahih Fikhi Sunnah (Jilid 1. Mesir: Maktabah taufikiyyah, 2013), h. 220 
kepada perintah orang tua, serta menyadari bahwa apa pun yang dilakukannya pasti diketahui Allah swt.

b. Syukur Terhadap Nikmat dari Allah wt.

Surah Luqman ayat 12 menyatakan tentang sifat Luqman yang selalu bersyukur kepada Allah swt. Dalam ayat tersebut dikatakan bahwa bersyukur kepada Allah swt pada hakikatnya adalah bersyukur untuk dirinya sendiri, Allah swt tidak rugi walupun manusia tidak bersyukur. Jadi, perilaku bersyukur sebenarnya untuk keuntungan manusia sendiri dan bukan untuk keuntungan Allah swt. Rasa syukur akan membuat manusia terhindar dari rasa sombong dan putus asa. Tanpa rasa syukur, kemungkinan besar manusia akan menjadi tamak atau rakus.

Sifat syukur merupakan landasan dalam sifat penghambaan manusia terhadap penciptaannya. Salah satu dasar tauhid dan penyembahan kepada Allah swt. Didasari atas rasa syukur kepada Allah karena telah menciptakan kita. Orang yang musyrik tidak mau bersyukur kepada Allah swt karena mereka lupa dan kufur terhadap proses penciptaan dirinya oleh Allah swt. Oleh sebab itu, kufur nikmat merupakan kufur terhadap Allah swt. Orang yang tidak bersyukur berarti menghina Allah swt. Durhaka, dan tidak mengerti siapa Allah swt sebenarnya. Tidak mungkin Allah swt akan menambah nikmat kepada orang yang tidak bersyukur, sebagaiman dinyatakan dalam QS Ibrahim ayat 7

Terjemahnya:

Dan (ingatlah juga), tatkala Tuhanmu memaklumkan; "Sesungguhnya jika kamu bersyukur, pasti Kami akan menambah (nikmat) kepadamu, dan jika kamu mengingkari (nikmat-Ku), Maka Sesungguhnya azab-Ku sangat pedih". ${ }^{23}$

Perlu diperhatikan bahwa pertambahan harta atau anak tidak selalu sejalan dengan pertambahan kenikmatan. Orang yang memiliki harta, namun tidak berkah pada umumnya tidak bahagia, misalnya dilanda penyakit yang berkepanjangan dan susah hati yang tiada henti. sementara itu, orang yang tidak memiliki harta yang banyak, namun berkah dapat saja bahagia karena dengan bersyukur ia dapat menikmati hidup dan selalu ada pertolongan Allah swt ketika ia membutuhkan.

Orang tua harus selalu menanamkan rasa syukur kepada anak sejak kecil. Biasakanlah anak bersyukur terhadap segala sesuatu yang diterimanya. Ingatkan mereka atas apa yang idperoleh dengan upaya yang maksimal, harus selalu disyukuri karena keberhasilan mereka disebabkan oleh izin Allah swt. Ingatkan anak untuk menyadari bahwa sangat banyak nikmat yang diberikan oleh Allah kepada manusia, misalnya nikmat menggunakan oksigen ketika bernapas, ceritakan bahwa orang yang membutuhkan bantuan oksigen dalam bernapas harus membayar dengan biaya yang

${ }^{23}$ Kementerian Agama RI, al-Qur'an dan Terjemah, (Bandung: Sygma Publishing, 2010), h. 
mahal untuk dapat bernapas, tentu saja, secara perlahan perlu ditekankan bahwa rasa syukur itu harus ditujukan kepad Allah swt dan bukan pada nikmat yang diberikan. Aplikasi syukur dilakukan dengan cara meningkatkan kualitas dan kuantitas ibadah kepada Allah. Jadi, orang yang bersyukur adalh orang yang memiliki amal shaleh dan ibadahnya kepada Allah swt selalu meningkat. ${ }^{24}$

\section{Pendidikan Akhlakul Karimah}

Luqman mendidik anaknya agar agar memiliki ahlaqul karimah, memiliki rasa soisal kemasyarakatan yang tinggi memiliki human ralationship yang kuat, mendidik anak untuk berbakti kepada kedua orang tua, tidak sombong dan congkak, ketika nanti sudsah menjadi manusia yang berstatus di masyarakat, hidup dalam kecukupan atau bahkan memiliki status atau posisi penting di tengah masyarakat. Diantara pendidikan akhlakul karima sebagai berikut:

a. Berbakti Kepad Kedua Orang Tua

Luqman memberi nasihat bahwa anak harus berbakti kepada kedua orang tua. Sudah seharusnya kita memuliakan dan menghormati orang tua karena keduanya yang memelihara kita, terutama ibu yang telah mengandung kita dalam keadaan payah. Orang tua memiliki rasa cinta dan kasih sayang terhadap anaknya. Perasaan tersebut dijadikan Allah swt sebagai asas kehidupan psikis, sosial, dan fisik kebanyakan makhluk hidup. Allah swt memerintahkan manusia untuk berbakti kepada kedua orang tua, sebagaiman didalam QS Luqman ayat 14. Perintah kepada anak agar berbuat baik kepada orang tua berulang kali disebutkan dalam al-Qur'an dan seruan Rasulullah. Seorang anak harus lebih mengutamakan ibunya karena seorang ibu telah banyak mengandung beban mulai dari kehamilan sampai kelahiran. Selama proses tersebut ibu dibebani oleh dua nyawa yakni nyawa sendiri dan nyawa anaknya.

Berbakti kepada kedua orang tua merupakan hal yang wajib jika kebaktian tersebut tidak bertentangan dengan ajaran Allah swt. Pertanyaan yang muncul adalah bagaimana jika orang tua menyuruh kita berbuat dosa atau musyrik, apakah jika perintahnya tidak dituruti lantas kita disebut durhaka kepadanya?', kondisi tersebut telah diantisipasi dalam ajaran islam, sebagaimana dinyatakan QS Luqman ayt 15. Jika orang tua menyuruh pada kemusyrikan maka gugurlah kewajiban untuk taat kepada orang tua, walau sangat besar paksaan atau rayuan yang diberikan oleh orang tua agar menyekutukan Allah swt. Allah memerintahkan kepada seseorang anak untuk tidak taat kepada orang tuanya jika mengajak pada kemusyrikan, namun Allah swt. Memerintahkan untuk tetap menjalin silaturahmi dengan baik.

Perintah untuk berbuat baik kepada orang tua juga dijelaskan di dalam hadis Nabi saw. Sebagaiman sabdanya:

${ }^{4}$ Ridwan Abdullah Sani, Muhammad Kadri, Pendidikan Karakter (Jakarta: PT. Bumi Aksara, 


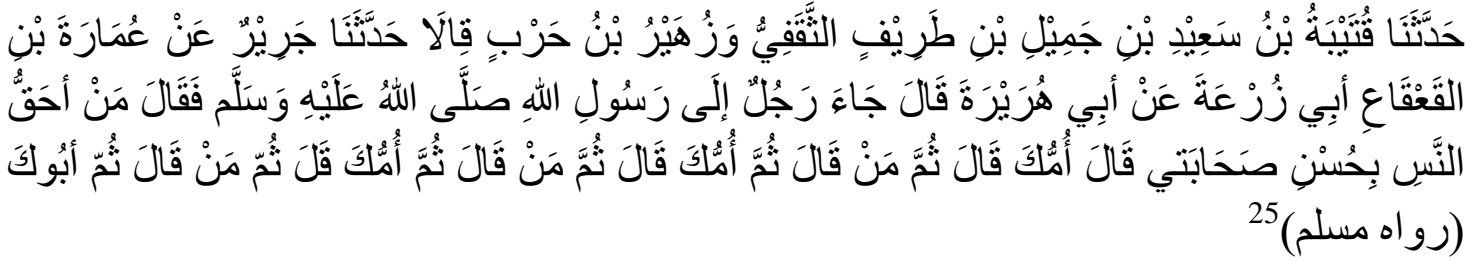

b. Mendiidk Anak untuk tidak Sombong

Luqman memberi nasihat kepada anaknya agar tidak sombong atas seuatu yang dimiliki karena pada hakikatnya segala sesuatu yang dimiliki di dunia adalah milik Allah swt. Hidup dalam kehidupan bermasyarakat akan aman jika tidak bersikap takabur, angkuh, dan sombong. Orang yang sombong akan dibenci oleh orang lain dan ada saja jalan untuk mendapat musibah. Masyarakat pada umumnya enggan menolong orang sombong yang terkena musibah. Perilaku sombong dan angkuh dalam berjalan di muka bumi sangat dibenci oelh Allah dan dibenci pula oleh manusia QS Luqman ayat 18. Dalam sebuah hadis juga dikatakan bahwa pada suatu hari Rasulullah saw. Sedang membicarakan masalah orang yang angkuh dan salah satu sahabat bertanya tentang perkara sombong kemudian Rasulullah saw. Bersabda

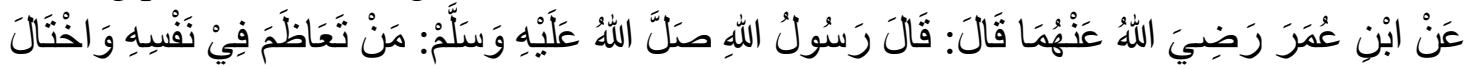

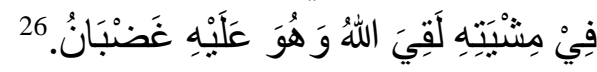

Terjemahannya :

Dari Ibnu Umar r.a. ia berkata: Rasulullah saw. Bersabda: "barangsiapa menganggap dirinya besar dan bersikap sombong dalam berjalan, maka ia akan menemui Allah dalam keadaan murka kepadanya.

Hadis diatas menjelaskan bahwa kesombongan itu nampak pada beberapa keadaan, diantaranya kesombongan ini nampak pada cara jalan seseorang, cara berpakaian, cara berbicara atau cara melihat. Jadi barang siapa menunjukkan sifat-sifat dalam perilakunya, maka niscaya manusia membenci dan mencelanya. Kemudian ia akan menjumpai Allah pada hari kiamat, sedangkan Allah marah padanya. Kemarahan Allah swt. Pasti mendatangkan siksaan. Untuk itu, maka sifat semacam ini merupakan salah satu dosa-dosa besar. ${ }^{27}$

\section{Dampak Nilai-Nilai Pembelajaran PAI dalam QS Luqman Ayat 12-19.}

\section{Terbiasa Mengikuti Syariat Allah}

Setiap mukmin wajib mencintai apa saja yang dicintai Allah dengan cinta yang mengharuskannya untuk mengerjakan apa saja yang diwajibkan Allah swt. Kepadanya.

${ }^{25}$ Abu Abdillah, Muhammad ibn Ismail ibn Ibrahim al-Bukhaari. Sahih Bukhari dalam kitab 9 imam hadits Ver. 1 (CD-ROM), Lidwa Pustaka i-Sofware, 2009, hadis no 4621

${ }^{26}$ Ibnu Hajar Al-Asqalani, Kitabul Jami' (cet. III. Yogyakarta: Belajar Islam, 2013 ), H. 89

27 Abdullah bin Abdurrahman Al-Bassam, Penjelasan Hukum dari kitab Bulughul Maram (Jakarta: Pustaka Azzam, 2016), h. 158 
Jika cintanya bertambah, ia mengerjakan apa saja yang di sunnahkan Allah kepadanya dan itu keutamaan darinya.

Orang mukmin juga harus membenci apa saja yang dibenci Allah swt. Dengan kebencian yang mengharuskannya berhenti dari apa saja yang diharamkan Allah kepadanya. Jika kebenciannya meningkat, sampai mewajibkannya berhenti dari apa saja yang makruh, maka itu keutamaan darinya. Imam ibnu rajab ketika menjelaskan hadis yang diriwayatkan oleh imam bukhari dan muslim Rasulullah bersabda

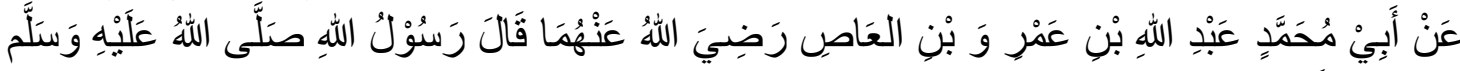

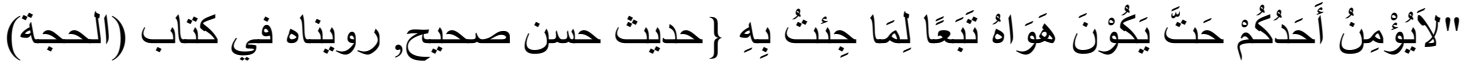
بإذناد صحيح 28

Artinya:

Dari abu Muhammad Abdullah bin Amr bin al-Ash r.a. ia berkata: "Rasulullah saw. bersabda: 'tidak sempurna iman salah seorang dari kalian sehingga keinginannya mengikuti apa yang aku bawah. (hadis hasan sahih, yang kami riwayatkan dalam kitab al-Hujjah dengan sanad yang sahih)

Cinta kepada nabi merupakan pokok (prinsip) keimanan dan ia bersanding dengan cinta kepada Allah swt. Dan Allah telah mengaitkan cinta kepada Nabi-Nya dengan cinta kepada-Nya serta mengancam orang-orang yang mendahulukan cinta kepada keluarga, harta, dan tanah air dari cinta kepada Allah dan Rasul-Nya.

Allah swt. Berfirman QS at-Taubah ayat 24

Terjemahnya:

Katakanlah: "Jika bapa-bapa, anak-anak, saudara-saudara, isteri-isteri, kaum keluargamu, harta kekayaan yang kamu usahakan, perniagaan yang kamu khawatiri kerugiannya, dan tempat tinggal yang kamu sukai, adalah lebih kamu cintai dari Allah dan RasulNya dan dari berjihad di jalan nya, Maka tunggulah sampai Allah mendatangkan keputusan NYA". dan Allah tidak memberi petunjuk kepada orangorang yang fasik. ${ }^{29}$

Begitu juga ketika umar r.a datang kepada Nabi saw. seraya berkata; 'wahai Rasulullah, engkau lebih aku cintai dari segala sesuatu kecuali diriku. Kemudian Nabi berkata: " tidak wahai Umar, sampai aku lebih engkau cintai daripada dirimu sendiri." Lalu Umar berkata " demi Allah, engkau sekarang lebih aku cintai daripada diriku sendiri." Maka Nabi berkata: "sekarang wahai Umar."

Maka, wajib mengedepankan cinta kepada Nabi saw. dari cinta kepada diri, anak, kerabat, keluarga, harta, tempat tinggal dan lainnya yang sangat dicintai

28 Yazid bin Abdul Qadir Jawas, Syarah Arba'in An-Nawawi (Jakarta: Pustaka Imam AsySyafi'i, 2016), h. 777

${ }^{29}$ Kementerian Agama RI, al-Qur'an dan Terjemah, (Bandung: Sygma Publishing, 2010), h. 190 
manusia. Dan cinta kepada Nabi tidak sempurna kecuali dengan mentaati perintah beliau. Allah berfirman didalam QS Ali Imran/3: 31.

Terjemahanya

Katakanlah: "Jika kamu (benar-benar) mencintai Allah, ikutilah Aku, niscaya Allah mengasihi dan mengampuni dosa-dosamu." Allah Maha Pengampun lagi Maha Penyayang. ${ }^{30}$

Jadi, barang siapa mencintai Allah dan Rasul-Nya dengan cinta yang tulus dari dalam hatinya, cinta tersebut mengharuskan hatinya mencintai apa saja yang dicintai Allah dan Rasul-Nya. Cinta tersebut juga mengharuskannyamembenci apa saja yang dibenci Allah dan Rasul-Nya, ridha dengan apa saja yang diridhai Allah dan RasulNya, murka kepada apa saja yang dimurkai Allah dan Rasul-Nya, dan beramal dengan organ tubuhnya sesuai konsekuensinya cinta dan benci ini. Jika ia mengerjakan dengan anggota tubuhnya yang bertentangan dengan itu semua, misalnya ia mengerjakan sebagian yang dibenci Allah dan Rasul-Nya, atau meninggalkan sesuatu yang dicintai Allah dan Rasul-Nya padahal sesuatu tersebut termasuk yang diwajibkan dan ia mampu mengerjakannya, maka itu menunjukkan cintanya kurang sempurna, karenanya ia wajib bertaubat kepada Allah swt dan kembali menyempurnakan cinta yang wajib. Abu Ya'qub an-Nahrujuri berkata: siapa saja yang mengaku mencintai Allah swt, namun tidak menyesuaikan diri dengan Allah dalam perintah-Nya, maka pengakuannya tidak benar. Setiap pecinta Allah namun tidak takut kepada-Nya adalah orang tertipu. ${ }^{31}$

2. Menumbuhkan Rasa Tanggung Jawab dan Amanah

Sikap tanggung jawab sangat penting untuk ditanamkan kepada anak-anak sejak dini, karena kelak akan mempengaruhi kualitas kepribadiaanya ketika dewasa nanti, dalam menjalani kehidupannya di masyarakat. Tanggung jawab itu berkaitan dengan menerima konsekuensi dari apa yang telah diperbuat, atau merupakan suatu keharusan untuk melakukan sesuatu. Seseorang yang bertanggung jawab berarti dapat dipercaya (amanah) dan diandalkan.

Anak perlu ditumbuhkan semangatnya, keinginan dan kepekaannya untuk bertanggung jawab, bukan dibebani secara terus menerus dengan berbagai tanggung jawab. Tanggung jawab tidak dapat dan tidak boleh dipaksa kepada anak, karena tidak akan dapat bertahan lama dan kontraproduksi. Tetapi penanaman tanggung jawab

54

${ }^{30}$ Kementerian Agama RI, al-Qur’an dan Terjemah, (Bandung: Sygma Publishing, 2010), h.

31 Yazid bin Abdul Qadir Jawas, Syarah Arba'in An-Nawawi (Jakarta: Pustaka Imam AsySyafi'i, 2016), h. 785 
disesuaikan dengan usia dan perkembangan berbagai keterampilannya (motorik kasar dan halus, berbahasa dan sebagainya).

Prilaku yang amanah merupakan sesuatu yang urgern sebab perintah menunaikan amanah berlaku untuk umum untuk setiap muslim memegang amanat, baik yang bersifat umum untuk ummat atau bersifat khusus untuk pribadi tertentu. Menjaga amanah diharuskan dalam segala hal, baik dalam diri, harta milik orang lain, barang titipan, tidak menipu dalam bermuamalah, jihad dan memberi nasihat, tidak menyebarkan rahasia dan aib orang lain, amanah dalam agama dengan mengerjakan yang diperintahkan Allah swt. Dan menjauhi larangan-Nya. Dan sebaik-baik pelajaran yang disampaikan Allah swt. Adalah menunaikan amanah dan memutuskan secara adil. Allah swt mengingatkan di dalam QS. An-Nisa/4: 58.

Terjemahanya:

Sesungguhnya Allah menyuruh kamu menyampaikan amanat kepada yang berhak menerimanya, dan (menyuruh kamu) apabila menetapkan hukum di antara manusia supaya kamu menetapkan dengan adil. Sesungguhnya Allah memberi pengajaran yang sebaik-baiknya kepadamu. Sesungguhnya Allah adalah Maha mendengar lagi Maha melihat.

Al-amanat lawannya al-khianat, yaitu membenarkan terhadap apa yang didengarkannya dan tidak mendustakannya sesuatu, melalui ketaatan, beribadah, menjaga titipan dan kepercayaan. Amanat juga merupakan niat yang diyakini manusia melalui ucapan lisan sebagai pembenaran iman dan melaksanakan semua yang diwajibkannya. Amanat yaitu sifat yang dapat dipercaya, jujur dan terhindar dari khianat. Sedangkan menurut istilah amanat adalah segala sesuatu yang dipercayakan kepada manusia baik yang menyangkut hak dirinya, hak orang lain, maupun hak Allah swt. $^{32}$

3. Dapat Membentuk Kepribadian yang Islami

Ciri khas kepribadian muslim adalah terwujudnya perilaku mulia sesuai dengan tuntunan Allah swt, yang dalam istilah lain disebut akhlak yang mulia ciri khas ini sekaligus menjadi sasaran pembentukan kepribadian Raulullah saw. bersabda:

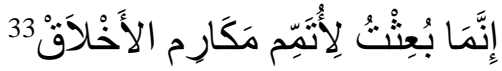

Artinya:

Sesungguhnya aku diutus untuk menyempurnakan akhlak yang mulia

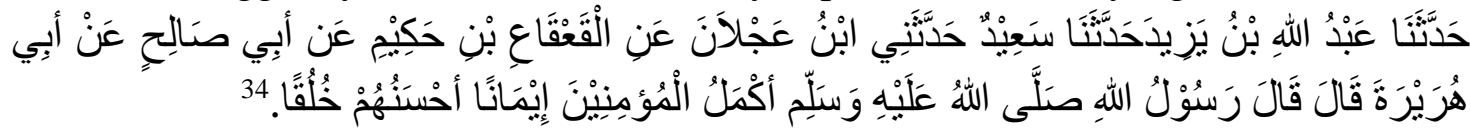

${ }^{32}$ Otong Surasman, Pendidikan Agama Islam (Jakarta, Erlangga, 2016), h. 101

${ }^{33}$ Izzan dkk, Hadis Pendidikan Konsep pendidikan Berbasis Hadis (Bandung, Perpustakaan Nasional Katalog dalam Terbitan, 2016), h. 239

${ }^{34}$ Mukhtar Samad, Gerakan Moral dalam Upaya Repolusi Mental (Yogyakarta: Sunrise, 2016), 
Artinya:

Telah menceritakan kepada kami Abdullah bin Yazid, dia berkata; telah menceritakan kepada kami Sa’id, dia berkata; telah menceritakan kepadaku Ibnu Ajlan dari Al Qa'qa' bin Hakim dari Abu Shalih dari Abu Hurairah, dia berkata; Rasulullah saw. Bersabda: “ orang mukmin yang paling sempurna imannya adalh yang paling baik akhlaqnya”

Tampak jelas bagaimana earatnya hubungan antara keimanan seseorang dengan ketinggian akhlaknya. Dalam memberikan analisanya tentang akhlak yang berhubungan dengan pembentukan kepribadian, Abdullah Darraz mengemukakan bahwa pendidikan akhlak berfungsi sebagai pemberi nilai-nilai islam. Dengan adanya nilai-nilai islam itu dalam diri seseorang atau ummah akan terbentuk pulalah kepribadiannya sebagai kepribadian muslim. ${ }^{35}$

\section{KESIMPULAN}

Metode pembelajaran PAI dalam al-Qur'an adalah metode pendidikan islam yang diungkapkan oleh beberapa pakar pendidik islam, diantaranya metode hiwar, (dialog), kisah (cesrita), keteladanan, nasihat dan pembiasaan. Diantara metode tersebut adalah merupakan model/cara dalam menyerap ilmu pendidikan.

Konsep pembelajaran PAI yang terkandung di dalam al-Qur'an khususnya yang terdapat di dalam surah Luqman ayat 12-19 pada dasarnya meliputi tiga hal yang sangat fundamental yaitu: pendidikan aqidah, pendidikan syariah/ibadah, dan pendidikan akhlak. Ketiga komponen tersebut merupakan satu kesatuan yang tak boleh dipisahkan guna terwujudnya pribadi-pribadi yang islami sesuai perintah al-Qur'an sunnah Rasulullah saw.

Dampak pembelajaran PAI dalam al-Qur'an surah luqman ayat 12-19 adalah terwujudnya pribadi yang terbiasa mengikuti syariat Allah swt, menumbuhkan rasa tanggung jawab dan amanah serta dapat membentuk kepribadian yang islami.

\section{DAFTAR PUSTAKA}

Kementerian Agama RI, al-Qur'an dan Terjemah. Bandung: Sygma Publishing, 2010.

Abd. Rahman Getteng. Pendidikan Islam dalam Pembangunan; Moral, Remaja, Wanita, dan Pembangunan. Makassar: Yayasan Al-Ahkam, 1997.

Abdul Ghoffar dkk, Tafsir Ibnu Katsir. Jakarat: Pustaka Imam Asy-Syafi'i, 2008

Majid, Khon Abdul, Hadis Tarbawi. Jakarta: Kencana Prenada Media Group, 2012.

Muin, Salim Abdul. Fiqih Siyasah; Konsepsi Kekuasaan Politik dalam al-Qur'an, Cet. III; Jakarta: Raja Grafindo Persada, 2002.

h. 44

\footnotetext{
${ }^{35}$ Ramayulis, Ilmu Pendidikan Islam (Jakarta: Kalam Mulia, 1994), h. 195
} 
Munir, Mulkam Abdul. Paradigma Intelektual Muslim Pengantar Filsafat Pendidikan Islam dan Dakwah. Yogyakarta: Gema Insani Press, 1994.

Departemen Pendidikan Nasional RI, Undang-Undang RI Nomor 20 Tahun 2003 tentang. Sisitem Pendidikan Nasional, Jakarta: Departemen Pendidikan Nasional Ri, 2003

Ramayulis. Ilmu Pendidikan Islam Jakarta: Kalam Mulia, 1994.

Surasman Otong. Pendidikan Agama Islam. Jakarta: Erlangga, 2016.

Izzan dkk. Hadis Pendidikan Konsep pendidikan Berbasis Hadis. Bandung: Perpustakaan Nasional Katalog dalam Terbitan, 2016.

Samad Mukhtar. Gerakan Moral dalam Upaya Repolusi Mental . Yogyakarta: Sunrise, 2016.

Jawas, Yazid bin Abdul Qadir. Syarah Arba'in An-Nawawi . Jakarta: Pustaka Imam Asy-Syafi'i, 2016.

Al-Asqalani, Ibnu Hajar, Kitabul Jami’. cet. III. Yogyakarta: Belajar Islam, 2013.

Abdullah bin Abdurrahman Al-Bassam. Penjelasan Hukum dari kitab Bulughul Maram. Jakarta: Pustaka Azzam, 2016.

Abdillah Abu, Muhammad ibn Ismail ibn Ibrahim al-Bukhaari. Sahih Bukhari dalam kitab 9 imam hadits Ver. 1 (CD-ROM). Lidwa Pustaka i-Sofware, 2009.

Abdullah, Sani Ridwan, Muhammad Kadri. Pendidikan Karakter . Jakarta: PT. Bumi Aksara, 2016.

Malik, Abu Kamal Bin Sayyid Salim, Sahih Fikhi Sunnah. Jilid 1. Mesir: Maktabah taufikiyyah, 2013.

Husain Abil, Muslim bin al Hajjaj al Qusyairie an Naisaburie. "Sohih Muslim", (Beirut, Libanon: Darul Fikri 2013.

Majid, Abdul Khon, Hadis Tarbawi. Jakarta: Kencana Prenada Media Group, 2012.

Rachman, Abdul Shaleh. Pendidikan Agama \& Pembangunan Watak Bangsa. Jakarta: PT Raja Grafindo Persada, 2005. 